\title{
STRATEGIC ANALYSIS OF THE EFFECTIVE DEVELOPMENT OF INDUSTRIAL ENTERPRISES ON THE BASIS OF THE USE OF "CORPORATE INNOVATION MANAGEMENT CHART"
}

\author{
Yuliia Klius ${ }^{1}$ \\ Volodymyr Dahl East Ukrainian National University, Ukraine \\ Vira Chizh ${ }^{2}$ \\ Cherkasy State Technological University, Ukraine
}

\begin{abstract}
Intensification of innovation activity of enterprises requires a qualitatively new organization of interconnections and interaction between all participants of the innovation process. The spreading of forms of corporate ownership and management in Ukraine has led to the development of corporate governance, whose strategic focus is becoming a top priority in the management of industrial enterprises. The introduction of an effective corporate innovation management system enhances competitiveness and economic efficiency by ensuring due attention to the interests of investors, management, and other participants in corporate relations; financial transparency, the introduction of effective management and control rules. The purpose of the article is to substantiate the use of "corporate innovation management chart" at industrial enterprises in conducting a strategic analysis of their effective development. Methodology. Methodological basis of the work is a set of methods and principles of scientific knowledge, general and special methods and techniques used during the study. The theoretical basis of the research is fundamental positions of the general theory of systems and innovation management, the theory of corporate management, scientific works of domestic and foreign scholars in the field of innovation management and corporate governance. The legal framework of the study is the current legislative and regulatory documents regulating the innovation activity of enterprises and corporate governance. For the achievement of the set purpose during writing of the article, the following methods are used: method of system analysis (for the definition of conditions of functioning of the corporate system of management of innovations); modelling (in the development of a mechanism for managing the effective development of an industrial enterprise with the use of "corporate innovation management chart"); graphic (for a visual representation of stages of creating a "corporate innovation management chart"). Practical implications. The obtained results and practical recommendations constitute the methodical basis for the formation of a corporate innovation management system. The results of the most practical significance include: directions of management of effective development of the industrial enterprise are revealed, the need to use "corporate innovation management chart" is proved, the necessity to create "corporate innovation management chart" is substantiated, types of these charts are considered, a model of "corporate innovation management chart" is developed, stages of creation of "corporate innovation management chart" are identified, the team's actions on creation of "corporate innovation management chart" at each stage are studied. Value/originality. It is substantiated that in order to make effective decisions under changes in the competitive environment, it is expedient for enterprises to use special forms of the planning of innovation activity. Form of such planning is the developed "corporate innovation management chart" as a special form of innovation planning, in which the achievement of strategic objectives of the enterprise is based on meeting the needs of consumers of innovative products by choosing organizational, industrial or technological innovations taking into account available resource possibilities for their implementation, which promotes, due to the possibility of viewing and updating the developed chart, making strategic management decisions in terms of changes in external and internal environment of the enterprise.
\end{abstract}

Key words: analysis, innovations, corporate management, development, chart.

JEL Classification: M41, O31, M14, M21

Corresponding author:

${ }^{1}$ Department of Accounting and Taxation, Volodymyr Dahl East Ukrainian National University.

E-mail: docentklus@gmail.com

${ }^{2}$ Department of Accounting, Analysis and Audit, Cherkasy State Technological University.

E-mail: chizhvera54@gmail.com 


\section{Introduction}

Development involves expansion of capabilities, potential, and has no limitations. In this sense, development is an effective redistribution of resources, primarily of an investment nature, in areas that ensure the highest possible competitiveness over the longest possible period, the improvement of goods and services (including on the basis of the existing organizational structure), the improvement of the structure and management systems, which result serves as an increase in demand for products of the enterprise, as well as the expansion of its economic activities. Thus, development as a qualitative change of an object can take different forms: transformation, emergence, formation, destruction, the creation of a new form or structure, transformation of content, connections, and dependencies. Any enterprise sooner or later resorts to innovation in order to maintain competitiveness and ensure effective development. As a rule, the introduction of innovations takes place against the background of production of core products, already well-known to market, due to which the accumulation of profits of the enterprise takes place.

To determine directions of innovation activity (type, scale of innovation), an analysis of the enterprise's innovation potential and marketing research to identify new market needs are conducted. Next, the enterprise needs to determine sources of funding for the innovative development of the enterprise and the optimal amount of investment funds. If the size of the investment is insufficient, it is more appropriate for the company to continue the production of existing products. If the enterprise manages to find the optimal amount of investment, which provides profit, the implementation of the innovation project and the launch of new products with their subsequent marketing to the market begin. In this process, the introduction of an effective corporate governance system for innovation is of great importance.

\section{Managing the effective development of the industrial enterprise}

The existing concept of the effective development of industrial enterprises needs to be finalized as it does not reflect a number of issues arising during the implementation of the strategy of innovation development at the enterprise, in particular, the need to divide available resources for current and innovative activities, the choice of investment direction, depending on specific conditions of the internal and external environment of the enterprise, mechanism of enterprise management in terms of development of innovations.

In order to ensure the strategy of effective development of the enterprise, a mechanism for the effective development management is needed. In order to effectively manage the enterprise development in terms of innovation, "corporate innovation management chart" can be used as a special form of planning, which helps to find effective solutions for changes in the competitive environment.

The traditional model of strategic management of the effective development of the enterprise is a consistent implementation of the following elements:

1. Goal: adaptation to changes due to the flexibility of internal processes and structures.

2. Principles: stability of the environment, predictability, etc.

3. Methods and systems of development: strategic planning and management, controlling, project management mechanisms.

4. Direction of the development process: continuous improvement.

5. Management system: the hierarchical structure of control and authority, the exact definition of rights, etc.

There are also a number of other models of effective development management, the greatest interest of which is the model of integration of strategic and innovative management of enterprises. The model represents a sequential implementation of the following key blocks:

1. Analysis: assessment of the external and internal environment, the definition of the mission, formulation of goals.

2. Planning: planning a strategy, setting tasks.

3. Realization: development of plans, carrying out of structural changes.

4. Control: budgeting, operational management; assessment and control.

This mechanism can be used when an enterprise plans to develop a strategy for its effective development.

Taking into account the above in Fig. 1, there is represented the mechanism for managing the effective development of an industrial enterprise, consisting of blocks: planning, organization, motivation, coordination, control, and analysis.

Each of the blocks highlights stages that are significant in terms of building a strategy for effective development:

1. Determination of purpose and objectives of effective development of an enterprise on the basis of innovative approach. At this stage, the enterprise determines the presence of internal resources, strengths and weaknesses, conducts market research, analysis of the management structure.

In the process of setting the purpose and objectives of an effective development of the enterprise, it is necessary to determine factors that ensure the effective development of the enterprise. External factors include factors of the external environment (macro- and microenvironment), on the impact of which the company cannot or almost cannot make an influence. Internal factors include factors of the internal environment, which the company can have a direct impact on. Among the many different factors of the effective development of an industrial enterprise, the following 


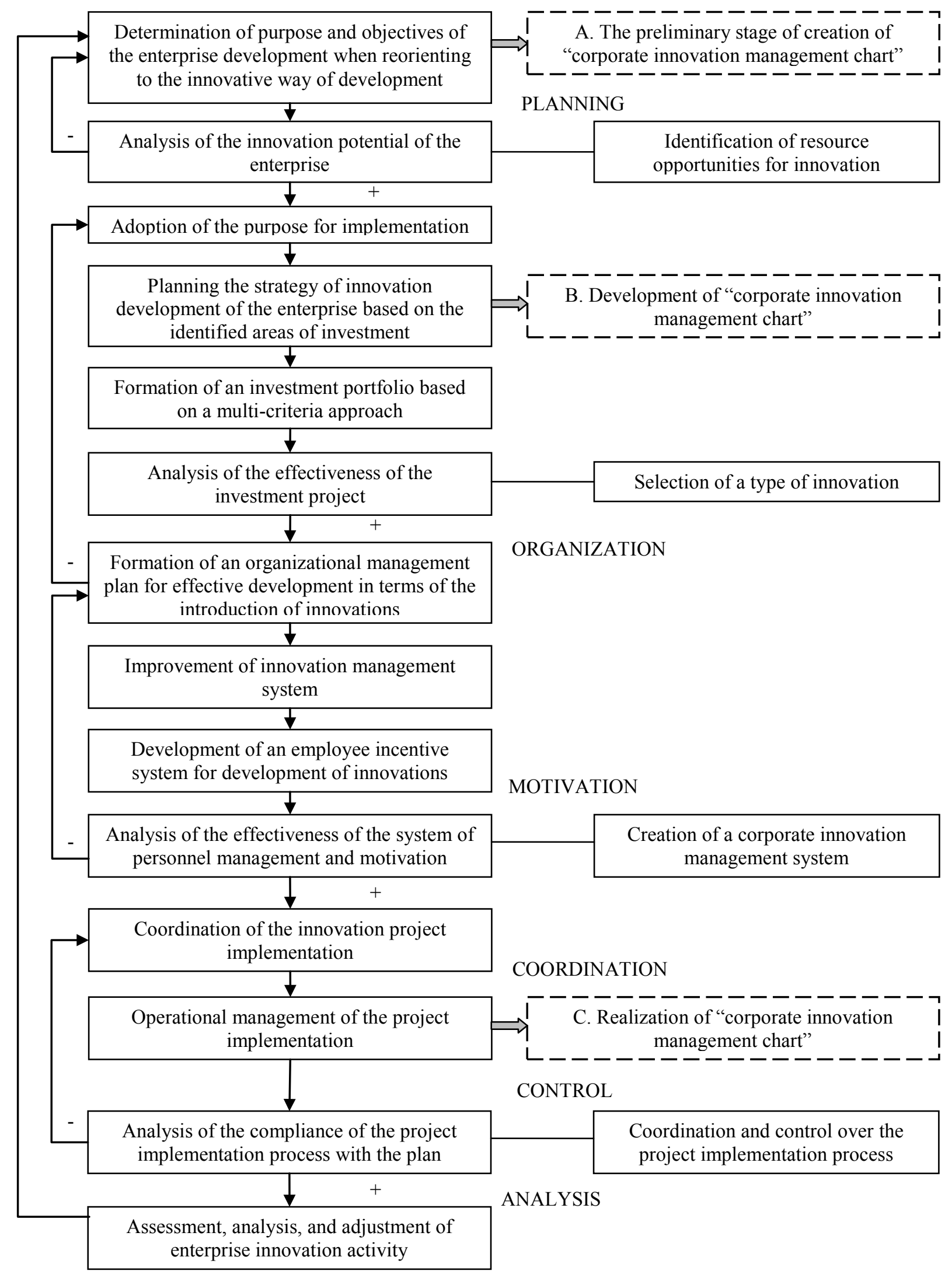

Monitoring of the environment

Fig. 1. Mechanism of management of the effective development of an industrial enterprise with the application of "corporate innovation management chart" 
can be distinguished: competitiveness of enterprises and products; monitoring of the external environment; production structure; level of personnel qualification; flexibility of the organizational structure; level of production specialization; cost and their dynamics; structure of financial resources; structure of information flows of the enterprise; availability of innovation and investment potential, etc.

It is necessary at this stage to analyse the innovation potential of the enterprise to identify opportunities for the enterprise in the implementation of innovation activities. This will allow excluding areas of activity that are not feasible for the enterprise. The result of this stage is the preliminary elaboration of "corporate innovation management chart".

2. Planning the strategy of innovative development of the enterprise on the basis of forming a corporate innovation management system. There are: a search for opportunities for investing in the most profitable and perspective directions, development of the strategy of innovation development, selection of a certain type of innovation, based on the enterprise possibilities. The result of this stage is the elaboration of "corporate innovation management chart".

3. Formation of an organizational management plan for the enterprise effective development in the context of introducing the corporate innovation management system. One should carry out an analysis of the existing organizational structure of the enterprise, identify directions of improvement of the innovation management system for its conformity with the chosen direction of development, and develop the system of personnel motivation for the development of innovations.

4. Coordination of the activity on the investment project implementation. At this stage, a clear synchronization of artists on time and resources is required in order to implement the project on time with the planned results.

5. Control. Operational management of the project, control over compliance with terms and funds allocated to the project are carried out, operational measures are implemented to ensure that the project is in line with the plan elaborated. The result of this stage is the implementation of "corporate innovation management chart".

6. Analysis. In order to identify the successes and mistakes, an analysis of the project results is carried out to take them into account in future enterprise activities. If necessary, adjustments are made to the enterprise activities based on conclusions of this analysis.

\section{Substantiation of the use of "corporate innovation management chart"}

In order to effectively manage the enterprise development in terms of innovation, it is possible to use "corporate innovation management chart" developed by the author by analogy with the use of a "roadmap". The application of principles of a "road map" is best known in the practice of managing companies in the USA during a period of weakening the economy. To date, the construction of a technological "roadmap" has become the main way of making strategic decisions in international business.

The main feature of using the method of creating a "corporate innovation management chart" is to unite creative groups of employees of the enterprise in order to jointly see the future of the enterprise. Using "corporate innovation management chart" in strategic planning should be based on teamwork, intensive knowledge sharing.

At the level of an individual enterprise, "corporate innovation management chart" can have different uses with a number of following advantages (Fig. 2).

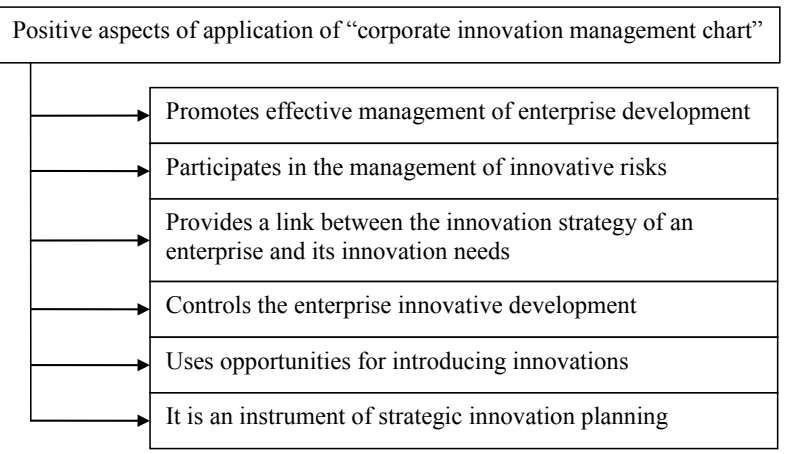

Fig. 2. Advantages of the use of "corporate innovation management chart"

The success depends on how principles and methods for creating a "corporate innovation management chart" can be agreed upon. Building a "corporate innovation management chart" can help strategic processes at all levels, set the same framework for all processes in the enterprise.

The main advantage of using the "corporate innovation management chart" is to provide accurate and clear information, a basis for effective decision-making and the provision of control tools. This is done by identifying the necessary processes, new opportunities for the enterprise or those mistakes that need to be addressed to develop competitive and realistic innovation development goals and plans.

One of the advantages of "corporate innovation management chart" is that the management is actually aware of the enterprise's needs and as a result either receives at its disposal the necessary processes to meet those needs or prepares the existing processes for this.

"Corporate innovation management chart" gives a priority to investments based on a certain list of key factors (drivers) and uses emerging opportunities. Also, "corporate innovation management chart" can be used as a strategic marketing tool to analyse which product is a key value for a company. Any "corporate innovation 
management chart" should explain the enterprise's needs to employees, management, clients, and all stakeholders, allowing them to understand where changes are needed to achieve effective development and to participate in these changes.

At the enterprise, it is possible to develop several types of "corporate innovation management charts" depending on specific needs. For example, a "corporate innovation management chart" may consist of scientific, technological, production, organizational charts (by analogy with "roadmaps").

Accordingly, different types of "corporate innovation management charts" have certain goals and a different time period, as well as varying degrees of importance for shareholders, managers, and business owners (Fig. 3).

The main direction of the strategy of innovation development of the enterprise, which is reflected in the "corporate innovation management chart" of the enterprise, is the most important and usually should be clarified in the first place. The key importance of scientific, technological, production and organizational charts is to set specific goals and take into account market needs. These private "corporate innovation management charts" should be the source of information for the elaboration of "corporate innovation management chart" of the enterprise. At the same time, there should be feedback - "corporate innovation management chart" of the enterprise should reflect the strategy, on the basis of which separate charts are drawn up.

In the process of creating an "innovation chart" of the enterprise, a properly formed creative team must be involved in order to systematize and provide the information necessary for planning. The ultimate goal of the team is to make effective investment decisions. "Corporate innovation management charts" should be created by senior managers with a certain knowledge,

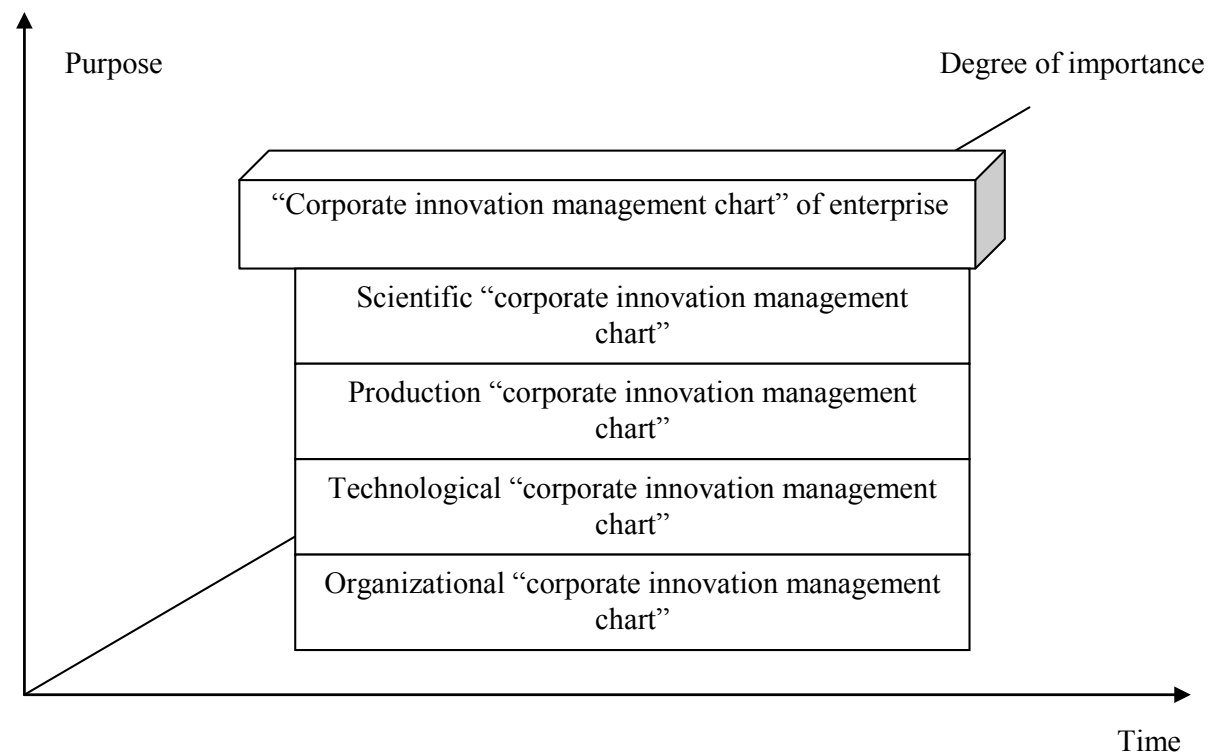

Fig. 3. A set of "corporate innovation management charts" at an industrial enterprise

Table 1

The main participants in the process of creating "corporate innovation management chart"

\begin{tabular}{|c|c|c|c|c|c|}
\hline Participants & $\begin{array}{c}\text { "Corporate } \\
\text { innovation } \\
\text { management chart" } \\
\text { of the enterprise }\end{array}$ & $\begin{array}{c}\text { Scientific } \\
\text { "corporate } \\
\text { innovation } \\
\text { management chart" }\end{array}$ & \begin{tabular}{|c|} 
Production \\
"corporate \\
innovation \\
management chart"
\end{tabular} & $\begin{array}{l}\text { Technological } \\
\text { "corporate } \\
\text { innovation } \\
\text { management chart" }\end{array}$ & $\begin{array}{c}\text { Organizational } \\
\text { "corporate } \\
\text { innovation } \\
\text { management chart" }\end{array}$ \\
\hline Top management & +++ & ++ & ++ & + & ++ \\
\hline Shareholders & +++ & ++ & + & + & + \\
\hline Employees of R\&D department & + & +++ & ++ & ++ & ++ \\
\hline Production management & + & ++ & +++ & ++ & ++ \\
\hline Technological management & + & ++ & ++ & +++ & ++ \\
\hline Marketing management & ++ & + & +++ & + & ++ \\
\hline Financial management & +++ & ++ & ++ & ++ & ++ \\
\hline Sales management & - & - & + & - & - \\
\hline Human resource management & ++ & + & ++ & ++ & +++ \\
\hline Quality management & - & ++ & ++ & ++ & ++ \\
\hline
\end{tabular}


skills, and experience with the participation of representatives of the $R \& D$ department, heads of production units, representatives of financial, marketing departments, and key employees of departments.

The procedure of forming an "innovation chart" refers to the participation of key stakeholders representing different levels and departments of the enterprise (Table 1).

The process of creating a "corporate innovation management chart" should start with a small team represented by employees of marketing departments, R\&D department, design department, as well as a department dealing with general management, development, production, and implementation of individual products. And only later, the team should be gradually supplemented by managers and shareholders. Team members must have principles of the chart creation process, as well as be able to identify needs and incentives for enterprise development.

\section{Creation of "corporate innovation management chart"}

Creation of "corporate innovation management chart" - is a planning process in order to identify, select, and develop a strategy for innovation development to meet interests of owners and shareholders and achieve the best results in the long run. One direction of action can be selected and a certain plan developed. If there is a great uncertainty or risk, then several directions can be selected, which can be followed simultaneously.

"Corporate innovation management chart" as a visual representation of the sequence of steps in time depends on a certain technique used by the enterprise. The main purpose of the method is to realize the correct steps and prepare for the future (Datsii, 2012). The process of creating a "corporate innovation management chart" consists of certain stages. If to consider it by the analogy with the creation of a "roadmap", then the process can take place in stages: identifying needs, reviewing and evaluating technology, confirming interrelationships between technology and needs; identifying requirements, benchmarking, technology monitoring, project creation, project evaluation, portfolio optimization. According to different approaches to the "roadmap" development process, in order to achieve the main tasks in the development of the "corporate innovation management chart", it is advisable to distinguish three stages (Fig. 4).

1. Preliminary stage.

2. Development of "corporate innovation management chart”.

3. Realization of "corporate innovation management chart”.

The process of creating a "corporate innovation management chart" begins with the study and analysis of the internal and external environment of the enterprise, which serves as a source of input information.

Initiating the process requires significant efforts, especially at early stages, when the mission, vision, strategic goals, resources, scale, team, and system of views are determined and agreed with the process of creating a "corporate innovation management chart". The research and analysis stage (A1) should include analysis of the enterprise's internal environment, analysis of external environment, skills, know-how, etc.

In the process of analysis, the need to create a "corporate innovation management chart" should be substantiated. Decision-makers need to figure out if they really are faced with a problem that can be solved by creating a "corporate innovation management chart". This should be done at the stage of problem setting (A2). Managers need to eliminate problems to meet their goals.

Once the essence of the problem has been clarified and a decision has been made to continue the project, the next stage is the definition of the mission and strategy (A3). The process of creating a "corporate

\begin{tabular}{|c|c|c|}
\hline \multicolumn{3}{|c|}{ Stages of the creation of "corporate innovation management chart" } \\
\hline & गु & $\sqrt{3}$ \\
\hline A. Preliminary stage & \multirow{2}{*}{$\begin{array}{l}\text { B. Development of "corporate } \\
\text { innovation management chart" }\end{array}$} & \multirow{2}{*}{$\begin{array}{l}\text { C. Realization of "corporate } \\
\text { innovation management chart" }\end{array}$} \\
\hline \multirow{2}{*}{$\begin{array}{l}\text { A1. Research and analysis } \\
\text { A2. Problem formulation } \\
\text { A3. Mission and strategy } \\
\text { A4. Statement of purpose } \\
\text { A5. Resources and budget } \\
\text { A6. Content and time } \\
\text { A7. Creating a project team }\end{array}$} & & \\
\hline & $\begin{array}{l}\text { B1. Formulating key questions } \\
\text { B2. Opportunities and risks } \\
\text { B3. Identification of alternatives } \\
\text { B4. Criteria and evaluation } \\
\text { B5. Preliminary evaluation } \\
\text { B6. Chart strategy } \\
\text { B7. Chart creation }\end{array}$ & \multirow[t]{2}{*}{$\begin{array}{l}\text { C1. Approval of the chart plan } \\
\text { C2. Discussion by managers } \\
\text { C3. Chart final report } \\
\text { C4. Report publication } \\
\text { C5. Chart implementation plan } \\
\text { C6. Periodic control and review } \\
\text { of the chart } \\
\text { C7. Report/plan of chart update }\end{array}$} \\
\hline & & \\
\hline
\end{tabular}

Fig. 4. The process of creation of "corporate innovation management chart" 
innovation management chart" helps to develop a common mission and vision of the future when the company faces the challenges it needs to cope with in order to achieve its goals. The implementation of the chosen strategy requires the definition of strategic goals (A4). These may be financial goals (achieving a certain amount of revenue growth, increasing profits) and nonfinancial goals associated with innovation, cost-effective management system.

Then the resources and budget (A5) should be determined: financial, human resources, know-how, information, technology, culture, real estate. For the purpose of efficient management, all resources should be listed in the statement of resources.

The content and length in time (A6) are also of great importance. At this stage, all accumulated characteristics are evaluated in order to eliminate uncertainty and solve emerging problems. The plan for managing the content of the project is one of the most important information documents at the enterprise. This document includes information on all the scale of work required to complete the project. It is also used to control.

At the previous stage, the team (A7), which consists of participants and process sponsors, is determined and approved (Tulenkov, 2005).

Upon completion of previous actions, the team of creating a "corporate innovation management chart" can begin to make it. The first stage of creating a "corporate innovation management chart" is the formulation of key issues (B1). Based on previous results, the team must decide, which area the chart will be targeted to.

Further to achieve the set goals (based on the stage of research and analysis), the general opportunities and risks (B2) should be assessed and the impact and likelihood of each opportunity or risk should be considered.

One of the important aspects of creating a "corporate innovation management chart" is identifying alternative strategies (B3). These alternatives may include an optimal, pessimistic, and neutral option. Understanding alternatives is a basis for determining which solution represents the greatest value, taking into account aggregate costs, total benefits, risks, and opportunities. It is necessary to identify, measure, and evaluate the costs, benefits, risks, and uncertainties associated with each alternative. The preferred solution must be consistent with appropriate timescales and necessary characteristics. It is also necessary to identify the priority objectives of "corporate innovation management chart" to achieve a balance between conflicting requirements. The team should define the criteria and rating system (B4), based on which planned options and success will be assessed.

Preliminary estimate (B5) of the feasibility of a better option is based on estimated financial costs and benefits in such a way as to see how they can be reconciled with the overall financial strategy.

Teammembers for "corporateinnovation management chart" should monitor whether these processes contribute to the implementation of the expected highlevel strategy of "corporate innovation management chart" (B6). It is necessary to make sure that the charts contain information from all stakeholders.

A chart must always have certain goals distributed over time. The best form of creating a "corporate innovation management chart" (B7) is a schedule that also has several goals and contributes to disseminating information about the result and strategic goals developed throughout the enterprise. There are several

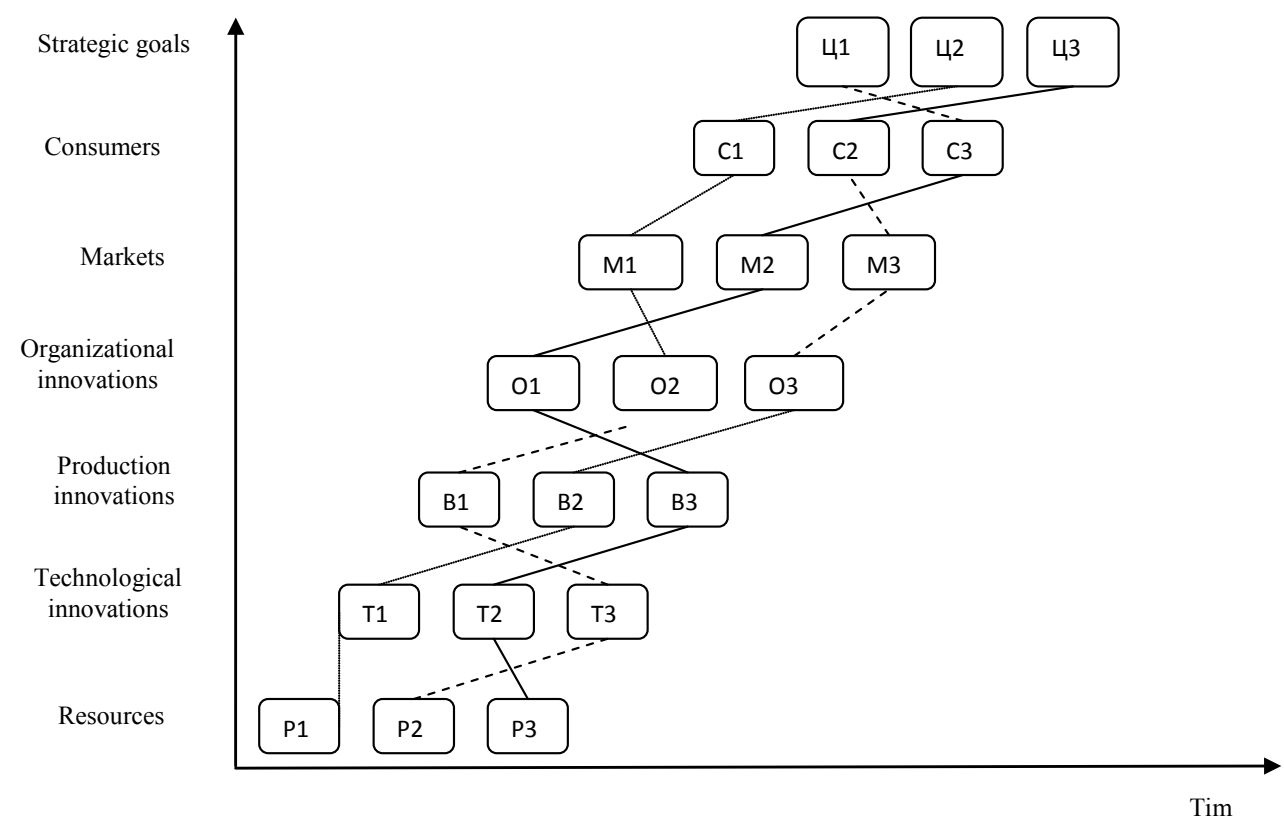

Fig. 5. Model of "corporate innovation management chart" 
ways to visualize the result of the process of creating a "corporate innovation management chart", one of which is shown in Fig. 5.

The completed process of creation of "corporate innovation management chart" should answer the following questions:

1. Why? (Strategic goals, resources, market needs, customer requirements, competitors, environment, industry trends).

2. What? (Processes, technologies, products, services, performance, basic principles).

3. How? (Strategy, culture, programs, knowledge, skills, equipment, infrastructure, standards, sources, projects).

4. When? (Plans, timetables, schedules, prolongation systems).

The third stage of creating a "corporate innovation management chart" is the implementation of this process. At this stage, the chart is reviewed, publicly announced, and implemented. This stage should include an analysis of the most important processes and competencies aimed at the successful implementation of "corporate innovation management chart".

The stage of approval of the "corporate innovation management chart" plan (C1) usually has two goals. First, within the framework of the working group, results of the process of creating a "corporate innovation management chart" are approved. Secondly, the process of advancement and promotion of recommendations proposed in the framework of the "corporate innovation management chart" program begins. After the working group completes the formation of the previous version of the "corporate innovation management chart", it spreads within the enterprise from a wide range of employees to get responses from different groups. Thus, it is desirable to organize a discussion of managers (C2) devoted to the data, problems, scientific expertise received during the creation of "corporate innovation management chart" for the purpose of drawing up a final report on the creation of a "corporate innovation management chart" (C3). After the publication of the general report (C4), separate implementation plans (C5) should be developed, resources distributed, and the chart should be implemented. The progress of its implementation is monitored, and the report is reviewed and updated as necessary (C7). The completed document should be a complex strategic plan.

\section{Conclusion}

Thus, the application of the "corporate innovation management chart" is aimed at supporting decisionmaking in implementing the strategy of innovation implementation at the enterprise. "Corporate innovation management chart" is a special form of planning that helps to find effective solutions for changes in the competitive environment.

The most important things in implementing the "corporate innovation management chart" are the following:

- effective prioritization;

- setting of criteria of responsibility;

- establishment of constant communication;

- checking the proper level of employee initiative;

- control that employees have the opportunity to directly participate in the creation of a strategy;

- confirmation of an explicit connection between the implementation of "corporate innovation management chart" and the system of efficiency management.

The proposed mechanism of an effective development management strategy can be used in cases when an enterprise plans to implement an investment project aimed at implementing innovations in order to effectively develop an enterprise. The selection of the project in 8 directions identified during the study, as well as the account of external and internal factors affecting the management system, will allow the enterprise to more effectively engage innovations in economic turnover, to select investment directions that ensure sustainable development of the enterprise.

\section{References:}

Garcia, M. L., Bray, O. H. (1997). Fundamentals of Teclmology Roadmapping. Sandia National Laboratories, Working Paper: 255-303.

Kappel, T.A. (2001). Perspectives on roadmaps: How organizations talk about future. Journal of Product Innovation Management: 25-30.

Hornyk, V. (2012). Concept and system of management of innovative development of industry of Ukraine. Bulletin of NAPA, 4: 168-174.

Datsii, O. (2012). Formation of a model of innovative enterprises. Bulletin of NAPA, 4: 174-179.

Tulenkov, N. (2005). Features of public administration in a transitional society. Ekonomika ta derzhava, 2: 12-14. 